\title{
The value of firm linkages in the age of industry 4.0: a qualitative comparative analysis
}

\author{
Mariachiara Barzotto $^{1}$ (D) . Lisa De Propris ${ }^{2}$
}

Received: 28 February 2018 / Accepted: 11 January 2021 / Published online: 13 February 2021

(c) The Author(s) 2021

\begin{abstract}
Over the years, manufacturing in advanced economies has been the object of intense reorganization driven crucially by the international strategies of multinational enterprises (MNEs), and more recently, by technological disruptions powering a new manufacturing model, defined as Industry 4.0 (I4.0). This paper aims to explore firm-based, place-based and global drivers that can determine high levels of companies' performance in the context of the emerging manufacturing model 'I4.0'. In particular, our article tests the relative importance of and balance between three determinants of MNEs' performance: (i) MNEs' internal operations and R\&D capabilities; (ii) reliance on local external economies and co-location with high-value service and technological competence; and (iii) the extent of MNEs' production in terms of spread across global value chains. We empirically address this issue by surveying top managers of MNEs operating in four advanced manufacturing industries (biotech, engineering, fashion, and new materials) and located in five European countries (Germany, Italy, Spain, Sweden and the United Kingdom). We adopt fuzzy-set qualitative comparative analysis, a configurational, case-oriented approach. MNEs can be highly profitable when they follow different, but equally successful, paths. Our findings shed light on which balance between firm-based, place-based and global drivers positively impacts on companies' performance in European advanced manufacturing sectors. In particular, we find that companies that collaborate with local suppliers of enabling technologies linked to I4.0 - with regard to the variety and intensity of collaborations- show high levels of performance. Policy implications are drawn in the concluding remarks.
\end{abstract}

JEL Classification $\mathrm{O} 14 \cdot$ F23

Mariachiara Barzotto

mb2602@bath.ac.uk

Lisa De Propris

1.de_propris@bham.ac.uk

1 School of Management, University of Bath, Bath BA2 7AY, UK

2 Birmingham Business School, University of Birmingham, University House,

Birmingham B15 2TT, UK 


\section{Introduction}

In the last decades, the industrial fabric of advanced economies has been reshaped primarily by the creation of global value chains (GVCs) coordinated by multinational enterprises (MNEs) and, more recently, by a disruptive wave of new technologies that are emerging and are expected to impact on sectors and markets (OECD 2017).

The internationalization of economic activities has led to the formation of GVCs (Gereffi et al. 2001) and, accordingly, global regionalism (Baldwin 2011) whereby production processes are sliced up and located worldwide. It is wellaccepted that MNEs have managed their GVCs by locating different functions in different parts of the world depending on their competitive advantage. MNEs' cost-saving strategies have led to the offshoring of the most labor-intensive production functions to low-cost economies. Offshoring has hollowed out many previously regionally based manufacturing (and related) sectors in advanced economies (Bailey and De Propris 2014; Hewings 2008; Nakamura 2010) and MNEs have progressively moved GVCs away from their domestic productive ecosystem, leading to a gradual dissipation of the local technological know-how, operational capabilities, and specialized skills (Pisano and Shih 2012).

A wave of new technologies (Ross 2016; Marsh 2013) is transforming the way firms organize production inside the factory and along the value chain; indeed, companies will be able to organize their activities more efficiently, collaboratively and resiliently by utilizing advanced information analytics (Lee et al. 2015), automation, robotics, sensoring, cloud technology - to mention only a few (for an overview, see: Frank et al. 2019). This new manufacturing model is referred to as I4.0. The adoption of I4.0 technologies (Brakman et al. 2015) offers companies in high-income regions the chance to reinvigorate and anchor manufacturing sectors by allowing them to enter viable market niches (Merlin-Jones 2012) and re-shore (Bailey and De Propris 2014) parts of their value chains (that is, move activities back to their home economies). A host of new technologies (OECD 2016) ranging from a variety of digital technologies to new materials and to new processes has increasingly impacted on business models of MNEs. Nowadays, companies create greater value by integrating products with the provision of digitalized services (Neely 2008; Parry et al. 2012). The increasingly dovetailing of manufacturing and high-value service functions, through processes of servitization, is fundamentally changing the nature of products, firms' business models and the modes of consumption from ownership to use (Vandermerwe and Rada 1988). Accessing and adopting such new technologies (and the competences and services attached to them) will have major implications for the strategies and performance of MNEs. In this article, we explore the extent to which MNEs can rely on resources that can be found either in-house or within their value chain- albeit global- and on resources that are pooled in the local context in which they are homed.

The objective of this paper is to understand what drives the performance of MNEs as they balance internal, locally embedded and international determinants, 
in particular in a context in which they are challenged by an emerging new manufacturing model, called I4.0. As MNEs constantly operate on multiple spatial scales, the present work explores the relative importance of and balance between three determinants of MNEs performance: (i) MNEs' internal operations and R\&D capabilities; (ii) reliance on local external economies and co-location with high-value service and technological competence; and, (iii) reliance on resources accessible from their global value chains. To investigate these issues, the article draws together the international business literature on the location choices and global value chains of multinational firms, that in the field of economic geography on the importance of place and agglomeration economies, and finally, the emergent literature on technological change and I4.0.

We collected primary data in 2017 with an online survey administrated to top managers of MNEs in Germany, Italy, Spain, Sweden and the United Kingdom (UK). We selected companies operating in four advanced manufacturing industries, namely: biotech (e.g., Semta 2009), engineering (e.g., European Commission 2019; Probst et al. 2013), fashion (e.g., Bontoux et al. 2017; Probst et al. 2013), and new materials (e.g., UK Government 2017; Singh et al. 2015). These manufacturing sectors were chosen because their production processes have been the object of intense cross-border fragmentation in the 1990s and early 2000s, and are now the object of robust policy initiatives at the national and EU levels (see, for instance, the European Task Force for Advanced Manufacturing) given their contribution to the EU's overall productivity and real income growth (European Commission 2013). We analyzed the interplay between firm-based, place-based and global drivers leading to a high level of firms' performance, via a fuzzy sets/qualitative comparative analysis (henceforth fs/QCA, Ragin 1987). The fs/QCA is a methodology able to detect different combinations of conditions that are necessary and sufficient to obtain the same outcome (Grandori and Furnari 2008).

The article will proceed as follows. The next section will frame the article in the current literature and formulate the hypothesis which is tested in Sect. 3, where the methodology, the data and the model are presented. Section 4 discusses the results and Sect. 5 offers some concluding remarks.

\section{Theoretical framework}

\subsection{In-house R\&D and production activities}

International business theories (e.g., Dunning 2000) and, in particular, internalization theory (e.g., Buckley and Casson 1976; Hennart 1982) evaluate the relative costs and benefits involved in MNEs coordinating economic activities ranging from internalization to more arm's length transactions (Buckley and Strange 2011). The use of arm's length transactions may suffer from a range of imperfections (DeGennaro 2005), which can be particularly significant when they involve knowledge-based assets and capabilities (e.g., R\&D). For this reason, companies tend to internalize them for better control (Buckley and Strange 2011). 
Offshoring strategies aimed at cost savings and efficiency optimization have led to a decoupling of labour-intensive tasks from knowledge-based tasks, with MNEs maintaining control over the latter. However, Zirpoli and Becker (2011) show that in the automotive industry, extensive offshoring and outsourcing have led to a loss of operational competencies critical to product innovation; this poses a risk to longterm innovation in companies. This danger is pertinent to both for craft-based industries (Breznitz and Murphree 2011; Buciuni et al. 2014) and those with a higher technological intensity (Ramirez 2016). Ketokivi and Ali-Yrkkö (2009: 35) find that "unbundling R\&D and manufacturing is possible for some companies but indeed a post-industrial myth of sorts for many others".

To deal with the new market scenario as well as recent technological challenges and ensure a company's successful performance, MNEs may need to complement their internally developed knowledge and resources by establishing inter-firm collaborations and relationships sourced at different geographical levels. Given the increasingly sophisticated combination of goods and services that manufacturing firms are pushed to offer in order to raise their revenues, Bellandi and Santini (2019) suggest that building out-factory relationships associated with local digital-based services might help foster the competitiveness of companies and their local productive system. However, accessing local digital-based services might not be sufficient to ensure successful financial performances. Hence, as indicated by the international business literature, companies tend to complement their internally developed and locally sourced knowledge with global resources through global networks of suppliers (Bathelt et al. 2004). Thus, in this article, we assess the extent to which internalized $R \& D$ and operations can contribute to a company performance vis-à-vis placebased (Sect. 2.2) and global (Sect. 2.3) dimensions.

\subsection{Industrial agglomeration and external economies}

Location matters and co-location matters even more. The extensive literature on clusters and industrial districts that has developed since the 1990s has discussed the benefits enjoyed by firms when they are 'meaningfully' co-located. Marshall (1980) claimed that industrial concentration promotes non-pecuniary dynamic externalities such as external economies, learning and innovation. Industries grow cumulatively in the same place because firms share a number of assets: for instance, specialized local labor markets. Studies on agglomeration economies have highlighted the importance of the so-called Marshall-Arrow-Romer externalities, namely that specialization in only one industry fosters its growth (Glaeser et al. 1992).

Too much specialization can, however, cause lock-in and a vulnerability in terms of the ability to react to shocks, due to a lack of alternative economic options for the regional economies; this, in turn, can lead to limited re-combinatory options (Frenken et al. 2007) available at the regional scale to recover from sector-specific shocks and/or generate new growth paths. Evidence has shown that the nature of the mix of economic activities embedded in a region determines its resilience. A variety of technologically related activities within a region offers companies opportunities for exploration, leading to gains in productivity, innovation and firm survival (Basile 
et al. 2017). Alternatively, there are bridging technologies that enable distant technologies to connect each other, producing more disruptive innovation (Corradini and De Propris 2017). To compete and survive in the global market, a manufacturing company needs to be able to tap into the competences, knowledge base and technologies of other sectors, and re-arrange them to create innovations (Boschma and Iammarino 2009). Firms located in economies characterized by the existence of a large variety of industries might increase their chances to generate between-sectors knowledge spillovers by interacting, replicating, and recombining ideas across different sectors arising from collaborations amongst companies (Jacobs 1969; Duranton and Puga 2001). Given the multiplicity and the increasingly sophisticated nature of knowledge embedded in products manufactured in developed economies (Hausmann et al. 2014), the establishment of strong links within the local production system becomes pivotal, both to fill companies' knowledge gaps and to advance local knowledge bases. In particular, previous studies highlight how a symbiotic relationship between knowledge-intensive business services (KIBS) and manufacturing firms represents an engine for territorial and company competitiveness (Lafuente et al. 2017), whereby collaborative partnerships between KIBS and product companies in advanced industrial economies plays a key role in enhancing them (Liu et al. 2019). Therefore, the embedded, immobile and cumulative knowledge and competences that a region offers, and that are shared across firms through local value chains can become either the pods enabling ambitions firms that venture abroad to become MNEs (De Propris and Crevoisier 2011), or an attractive destination for foreign MNEs seeking to access sticky knowledge (Asheim and Isaksen 2002).

A recent debate has overcome the often space-neutral approach to studying the location strategies of MNEs and found that, despite their footlooseness, MNEs take decisions, firstly, on offshoring after assessing the embedded assets that regional and national contexts can or cannot offer and, secondly, on the location of their activities, considering the immobile features of the host locations (Phelps 2008; De Propris and Driffield 2005; Gugler et al. 2015; Barzotto et al. 2017). As a consequence, the strategies and the performance of MNEs depend on their role as gateways between local and global systems of production and knowledge. Their ability to scout for knowledge globally through their global value chains does not diminish their reliance on more localized sources of competence and services. In contrast, their ability to integrate knowledge arising from global connections with contextual knowledge localized in the area in which they are homed enhances innovation and competition (Becattini and Rullani 1996).

\subsubsection{Industry 4.0 and information and communication technology competences}

I4.0 technologies are shaping a new manufacturing model that will impact on companies' linkages locally as well as globally. Manufacturing systems are vertically networked within factories and "horizontally connected to spatially dispersed value networks that can be managed in real time [...]. These developments make the distinction between industry and services less relevant as digital technologies are connected with industrial products and services into hybrid products" (Smit et al. 2016: 20). 
It is expected that MNEs will be the first recipients of the current technological disruptions that are transforming industries in advanced manufacturing systems (Tao et al. 2017) via networks of computer-integrated interconnected environments (Yew et al. 2016). A crucial part of I4.0 is the extensive application of digitally enabled technologies in production and marketing. In this context, the reliance of firms on information and communication technology (ICT) competences is of interest in this work since they can reside in talent inside the firm or in independent specialized providers that MNEs access via outsourcing. ICT-related industries, underpinned by digital competences, provide a growth platform for other industries as a new technological paradigm is emerging (Castellacci 2008; Martynovich and Lundquist 2015). As Verspagen (2004) demostrates, ICT-related industries have greatly impacted on the structure of the economy, complementing (instead of substituting) older technologies.

Given this new wave of technological transformations, this article explores how important it is for companies to have access to technologies alongside other determinants of their performance such as local and global linkages.

\subsection{Global players and global linkages}

MNEs are important global actors; their strategies and operations constantly reshape the nature of the global economy (Coe et al. 2004). They include multi-plant, multiproduct and multi-national firms that control or coordinate production activities across more than one country through networks that channel goods, services, knowledge, innovation and talent. The GVC (Gereffi et al. 2001) and global production network literature has focused on understanding the dynamics of the offshoring and outsourcing strategies used by MNEs, demostrating how MNEs use international sourcing to seek either cost savings and agility or higher quality inputs for more efficient production.

In technologically intensive fields, the depth and breadth of specialized knowledge required to develop new products/processes make it impossible for prime contractors to master all of the necessary knowledge (Beckman and Sinha 2005). Suppliers provide access to complementary information more quickly, at less cost, with less risk and with more flexibility compared than would be possible if a company were relying entirely on internal capabilities (Powell 1998; Rebolledo and Nollet 2011). Andersson and Stone (2017: 877) explore the ICT manufacturing industry and find that firms that are deeply integrated in global sourcing networks are closer to both their own production frontier and to the industry efficiency frontier.

Similarly, in buyer-driven supply chains, knowledge sharing between supply chain partners can enhance the performance of those partnerships by improving the understanding of customer needs (Myers and Cheung 2008). The main advantage of today's MNEs is that they are able to master system integration (Crescenzi and Iammarino 2017)- i.e., the complex coordination of activities combining different products, services, technologies and knowledge across spatial and functional boundaries (Malecki 2010). The task of system integration is currently amplified by the market 
pressure to develop more complex products and by servitization trends; that is, the growing orientation to provide customers with solutions which blend technologies, products, and services (UNCTAD 2015).

As knowledge inputs are increasingly derived from more sources and result in more complex outputs, MNEs need to organize and synthesize knowledge springing from a variety of sectors, locations, and cultural settings (Malecki 2010). Although MNEs are well-known for being nomadic, they are also important bridges between the local- and the global-scale of economic activities (De Marchi et al. 2017). They channel not only goods and services but also knowledge through buyer-supplier linkages. MNEs play a crucial role in connecting in-house knowledge with a local buzz (Bathelt et al. 2004; Storper and Venables 2004) and also external knowledge seeping through global networks of suppliers, collaborators and customers. Knowledge sourced from global suppliers can complement and/or substitute sets of knowledge bundled within firms as well as within the local socioeconomic fabric in which the company is located. Indeed, the competitive advantage of MNEs is deeply linked to how effectively they are able to manage knowledge flows via intra-firm global ties as well as inter-firm connections with suppliers. They can act as gatekeepers, sieving ideas and information, or as translators, by facilitating transmission and adoption (Bathelt et al. 2004).

New digital technologies are reshaping the business environment and the business model as companies face an innovation-production-consumption continuum characterized by co-innovation with consumers in the design and personalization of products as well as co-innovation in the delivery. New technologies also impact on the organization of production within and between firms, whether they are co-located in the same area or are linked by globally stretched supply chains (De Propris and Bailey 2020). In order to deal with these transformations, companies need to access, absorb and combine a variety of knowledge bases. They can do so at different geographical scales (Martin et al. 2018) and via a range of mechanisms (Trippl et al. 2009); such as: market mechanisms, networks (such as communities of practice), hierarchies (e.g. internalized R\&D and operations) and unintended spillovers (e.g., via human capital mobility) (Bellandi et al. 2020). The geographical radius available for companies in terms of accessing new knowledge depends on their absorptive capacity, characterized both by the ability to tap into knowledge that is spatially distant and the preparedness to use such new knowledge. In order to improve their financial performance, companies can follow alternative (but equally successful) paths by procuring the resources they need in different geographic loci and via different mechanisms. There is no one-size-fits-all approach. Companies can achieve successful financial performance by employing different combinations of firm-based (internalized R\&D and operations), place-based (accessing to I4.0 technology or a diverse local manufacturing economy) and global factors (accessing to a global network of suppliers via GVC). In light of the complexity and multi-scalar nature of companies' economic activities and the emergence of a new technological paradigm, in this article, we assess the impact of firm-based, place-based and global factors on companies' performance by testing the following hypothesis:

Internalized $R \& D$ and operations, access to I4.0 technology, access to a diverse local manufacturing economy, and access to a global network of sup- 
pliers via GVC can contribute- in a number of different, but equally valuable, combinations to the delivery of high levels of company performance.

\section{Methods and data}

\subsection{Methodology}

We apply a fuzzy-set qualitative comparative analysis (fs/QCA) methodology (amongst others: Medina 2016; Marra 2014; Marr 2012; Mas-Verdu et al. 2016). This methodology combines case-based research with Boolean algebra and a settheoretical approach to enable systematic and formalized cross-case comparisons (Ragin 1987,2008). fs/QCA methodology conceptualizes cases as a combination of causal conditions alongside the outcome (Schneider et al. 2010). Configurations are typically represented in terms of the presence or absence of the multiple conditions analyzed. The aim of this methodology is to identify the minimum number of configurations that are more consistently associated with the outcome of interest.

The rationale behind the use of fs/QCA is threefold. Firstly, the fs/QCA method differs "from conventional, variable-based approaches since they do not disaggregate cases into independent, analytically separate aspects but instead treat configurations as different types of cases" (Fiss 2011:401). fs/QCA methodology handles significant levels of causal complexity. In contrast, linear regression analysis and multivariate techniques cannot go beyond two- or three-way interactions (which are difficult to interpret) (Fiss et al. 2013; Grauvogel and Von Soest 2014). Secondly, fs/ QCA captures multiple paths to reach the same outcome (equifinality, Fiss 2007), which enables alternative actions to be identified in order to reach the desired result. Thirdly, fs/QCA allows us to identify the necessary and/or sufficient conditions by which companies attain high levels of innovation performance.

Through a so-called calibration process, primary data are converted into measures of set membership, then anchored and grounded in decisions using theoretical or substantive knowledge from sources external to the empirical data (Ragin 2008). Given the small number in the sample, we consider all configurations that have at least one case. Accordingly, we set the frequency threshold of the analysis to 1, which is the commonly accepted threshold for small-N QCA studies (Greckhamer et al. 2013; Aversa et al. 2015).

Necessity and sufficiency analyses: The first step in an fs/QCA study is to test if any of the four causal conditions, and their negations, are necessary for the outcome to occur. A condition is necessary if- whenever the outcome is present- the condition is also present (Schneider and Wagemann 2012). Conventionally, a condition or a combination of conditions is "necessary" or "almost always necessary" if the consistency ${ }^{1}$ score exceeds the threshold of 0.9 (Schneider et al. 2010).

\footnotetext{
${ }^{1}$ Consistency is measured as the number of cases featuring both a given configuration and the outcome divided by the number of cases featuring the same configuration, but not featuring the outcome (Ragin, 2008). Further details are provided in the results and discussion section.
} 
The second step in an fs/QCA study is to perform the sufficiency analysis. A causal condition is considered sufficient to significantly explain the outcome if such an outcome always occurs in conjunction with the related condition.

\subsection{Data}

Data were collected in 2017 via an online survey targeted at top managers ${ }^{2}$ (chief executive officers, human resource managers, managing directors, and operations managers) in medium-large MNEs. We adopt Dunning's (1981) definition of MNEs as "firms that engage in foreign direct investment"; thus, MNEs have production operations in two or more countries.

In this article, we surveyed MNEs (23 headquarters and three branch plants) based in five high-income European countries representative of Northern Europe (Sweden), Southern Europe (Italy and Spain), and Western Europe (the UK). These countries differ in terms of manufacturing and ICT presence, allowing the impact of a variety of regional industrial compositions on company performance to be assessed. We selected MNEs from four advanced manufacturing industries: the biotech, engineering, fashion and new materials sectors.

The study was administered ${ }^{3}$ through Qualtrics, a third-party online survey administration company (Long et al. 2011). Recent research has acknowledged Qualtrics as a reliable means of gathering data (amongst others: Courtright et al. 2016; DeCelles et al. 2012). All participants had random identifiers generated by Qualtrics, both to ensure confidentiality and anonymity and to permit the subjects to be more candid in their responses (Courtright et al. 2016: 1641). Participants were invited to take part in a study and fill out a survey on firm performance in the context of current technological transformations. Those who participated received $£ 60$ in compensation in exchange for approximately $45 \mathrm{~min}$ of their time (Fragale et al. 2012).

A stratified purposive sampling method was used to allocate each company in the different subgroups (Billing and Bryson 2019); cases were "selected in proportion to one or more characteristic in the population" (Gorard 2013: 81). We identified the cases according to three characteristics: firstly, their size, according to number of employees (50-249, or 250 or more employees); secondly, the sectors in which each operates (biotech, engineering, fashion or new materials); and thirdly, their location (Italy, Spain, Sweden or the UK). The stratified approach allowed for maximum diversity in terms of research participants (Billing and Bryson 2019).

This procedure yielded a total sample of 26 cases, ${ }^{4}$ corresponding to a $19 \%$ response rate. This result is consistent with the overall expected participation

\footnotetext{
${ }^{2}$ The rationale for targeting medium/large companies' top management is that top managers have a deep knowledge of their firm's characteristics and the environment in which their company operates. Furthermore, top managers are responsible for making strategic choices.

3 We did not have direct contact with the participants, but instead relied on the Qualtrics firm to recruit participants who could provide evidence of serving a company as a top manager (Galperin et al. 2019).

4 The number of cases is in line with fs/QCA's original purpose, which is to examine small and medium databases (e.g. < 50 cases) (Collier, 1993).
} 
rates in internet research using long (30-45 minute completion time) questionnaires (Deutskens et al. 2004; Marcus et al. $2007-17.1 \%$ and 18.6\% response rate, respectively).

Each participant was asked to provide some general information about the company (e.g. firm's country and region, ownership status, employee numbers, sector, profit growth, respondent's role in the company), information on the firm and its business environment (e.g. the extent of control over operations and R\&D activities, sectors present in the region and collaborations between sectors located in the same region), its supply chain (e.g., whether the company would be described as an original equipment manufacturer and their location of their key suppliers).

Respondents included the following: six chief executive officers, seven human resource managers, five managing directors, and eight operations managers. Twentythree percent of the companies surveyed had from 50 and 249 employees; the remainder, $77 \%$ had 250 or more employees. Table 1 reports the main characteristics of the surveyed companies. In terms of location, six companies were located respectively in Italy, five in Spain, five in Sweden, and five in the UK. The analysis of the dataset indicates that about $15.3 \%$ of companies are operating in the biotech sector, $15.3 \%$ in fashion, $15.3 \%$ in new materials and about $54 \%$ in engineering (see Table 2). The higher stratum of companies in this last sector is due to its contribution to the development of technologies applied in the new manufacturing model, I4.0.

\subsection{Variables}

\subsubsection{Outcome condition}

Building on Potter and Watts (2011), we measured company performance (PR) as the outcome condition with the financial performance indicator: profits growth, over five-year period (2012-2016). Investors and managers have widely considered profit growth as a factor of fundamental importance when evaluating firm performance (Morgan et al. 2009), or, more specifically, a firm's innovation performance (Divella 2017). The five-year period was chosen as it is a common timeframe in strategic management literature (e.g. Weinzimmer et al. 2012; Doyle and Hooley 1992). In QCA terms, profit growth can take one of two values: 1 if profits increased over the five-year period and 0 otherwise (Demirel and Parris 2015).

\subsubsection{Explanatory conditions}

We chose four sets of explanatory conditions: in-house R\&D and production location choice (firm-based driver), regional manufacturing and ICT services (placebased drivers), and international supply chain (global driver).

Set 1: We captured the firm-based driver using "in-house co-location $R \& D^{5}$ and production" (INHOUSE). To build this condition and translate the intensity of

\footnotetext{
5 With regard to operations and R\&D activities, companies were asked to declare the percentage $(>50 \%$, $50 \%$ and $<50 \%$ ) of each of these two activities which was undertaken in-house domestically.
} 


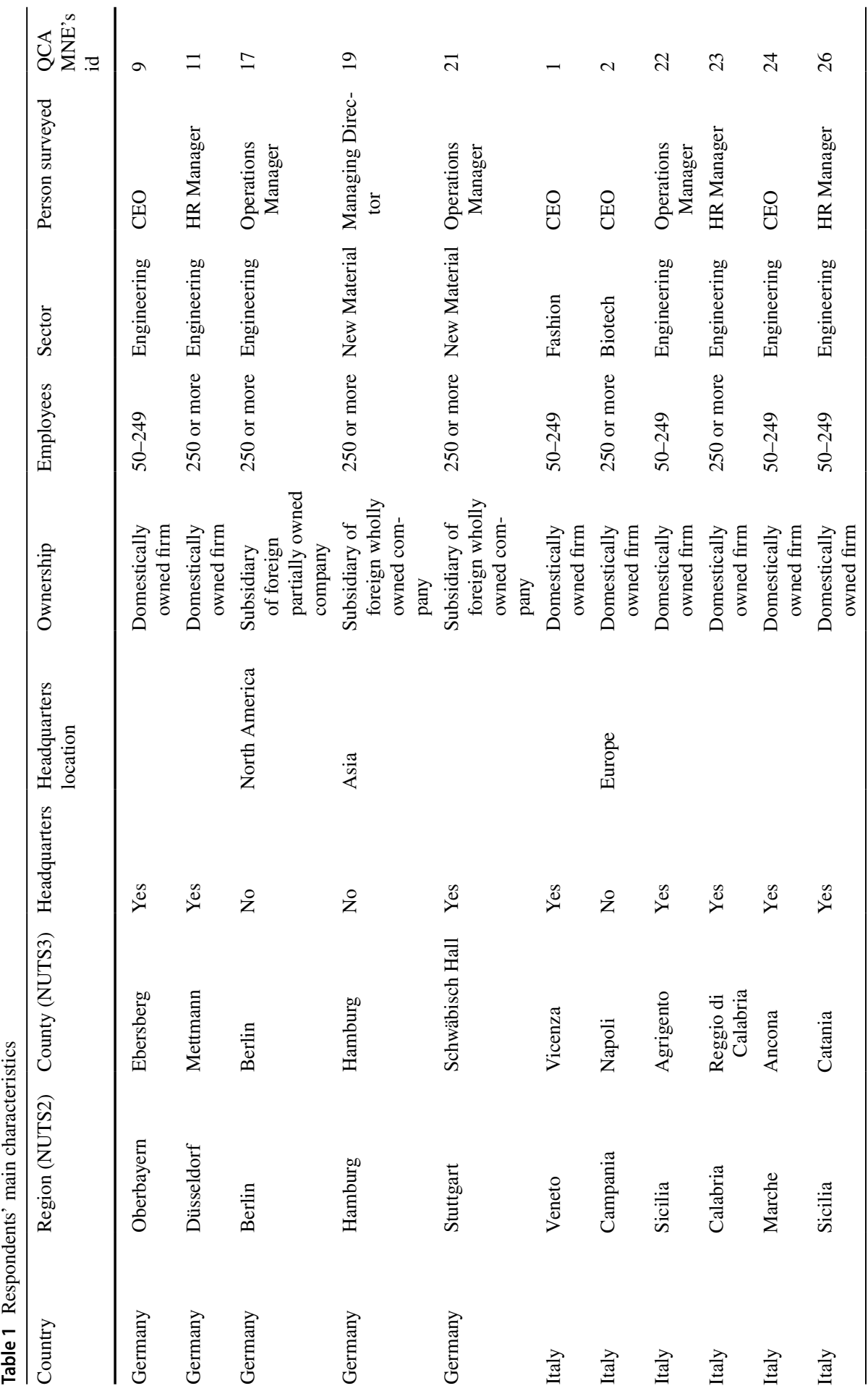




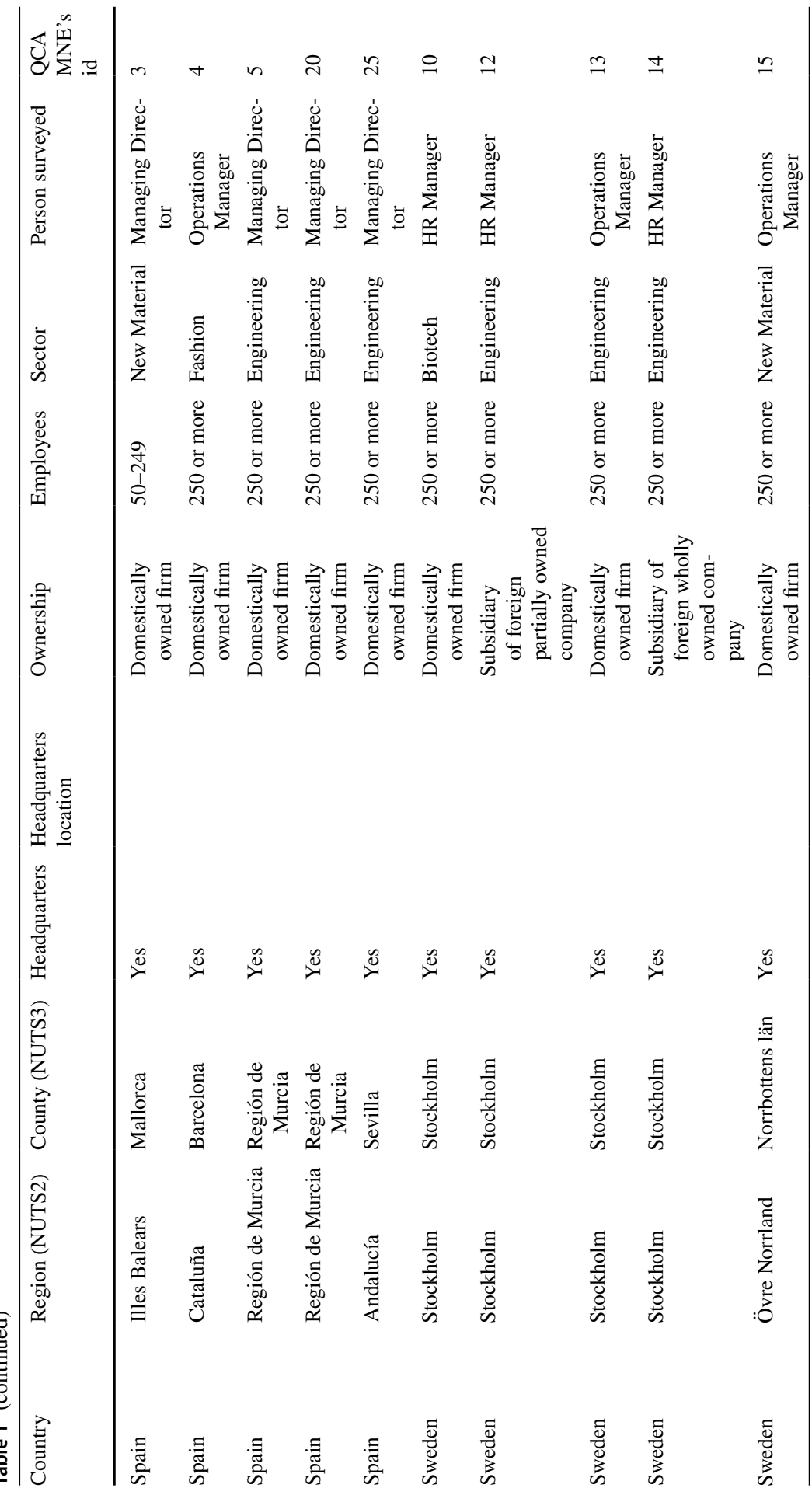




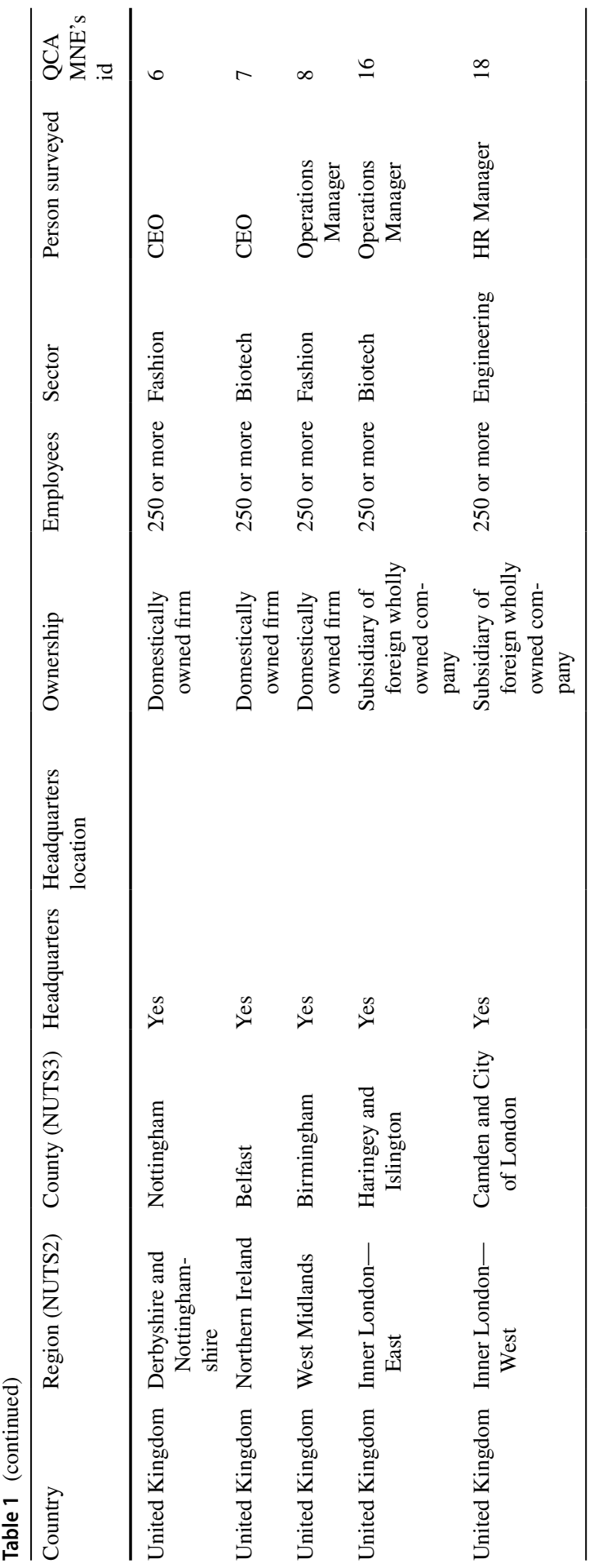


Table 2 Respondents by country and sector

\begin{tabular}{llllll}
\hline Country & \multicolumn{2}{l}{ Sector } & & Total \\
\cline { 2 - 5 } & Biotech & Engineering & Fashion & New material & \\
\hline Germany & 0 & 3 & 0 & 2 & 5 \\
Italy & 1 & 4 & 1 & 0 & 6 \\
Spain & 0 & 3 & 1 & 1 & 5 \\
Sweden & 1 & 3 & 0 & 1 & 5 \\
United Kingdom & 2 & 1 & 2 & 0 & 5 \\
Total & $4(15.3 \%)$ & $14(54.1 \%)$ & $4(15.3 \%)$ & $4(15.3 \%)$ & 26 \\
\hline
\end{tabular}

the co-location between operations and R\&D into a QCA membership score, we attached value 1 (fully in) if a company carried out $50 \%$ or more of both operations and R\&D activities in-house domestically; 0 (fully out) otherwise.

Set 2: To capture place-based drivers, we investigated MNEs' collaborations with other manufacturing firms and with firms offering ICT services in the local economy. We defined the condition "local manufacturing pool" (LOCMAN) as the extent to which (scale from 0 for low presence to 100 for high presence) ${ }^{6}$ companies declared themselves to be involved in joint commitments of resources with other firms in other manufacturing sectors ${ }^{7}$ within the home region. We computed this variable as the number of intense local collaborations (above 50\%). We used a direct method of calibration (Ragin 2008), with the following thresholds: 1 for full set exclusion, 2.5 for set crossover, and 5 for full set inclusion. ${ }^{8}$

In the light of the recent technological transformations, we explored MNEs' collaborations with firms offering ICT services with three conditions: (1) "I4.0 Service Collaboration Variety" (SERVAR); (2) "I4.0 Service Collaboration Intensity" (SERINT); and (3) "National Outsourcing KIBS" (NATKIBS). SERVAR captures the variance in the extent to which MNEs undertake activities involving joint commitments of resources with firms operating in I4.0 enabling technologies ${ }^{9}$ and located

\footnotetext{
${ }^{6}$ If managers declared a manufacturing sector presence above 20 , they were asked to state the extent to which their companies undertake activities involving joint commitments of resources with firms in 10 different manufacturing sectors located in their region.

7 These include: (1) manufacturing of textiles, apparel, leather and related products; (2) manufacturing of wood and paper products, and printing; (3) manufacturing of coke, and refined petroleum, chemicals and chemical products; (4) manufacturing of pharmaceuticals, medicinal chemical and botanical products; (5) manufacturing of rubber and plastics products, and other non-metallic mineral products, basic metals and fabricated metal products, except machinery and equipment; (6) manufacturing of computer, electronic and optical products; (7) manufacturing of electrical equipment; (8) manufacturing of machinery and equipment N.E.C.; (9) manufacturing of transport equipment; (10) other manufacturing.

8 The calibration of full set inclusion thresholds is justified by considering intense collaborations with at least five sectors out of 10 . The other thresholds are computed accordingly.

9 If managers declared a presence of ICT sector above 20, they were asked to state the extent to which (scale ranging from 0 for low joint activities to 100 for high joint activities) their companies undertake activities involving joint commitments of resources with firms in four different ICT sectors located in their region: (1) data, computational power, and connectivity (big data/open data, Internet of Things/M2M, and cloud technology); (2) analytics and intelligence (digitization and automation of knowledge work, advanced analytics); (3) human-machine interaction (touch interfaces, virtual and aug-
} 
within their own regions. We computed SERVAR as the standard deviation of these collaborations. We used a direct method of calibration (Ragin 2008), with the following thresholds: 25 th percentile for full set exclusion, 50th percentile for set crossover, and 75th percentile for full set inclusion. We computed SERINT as the number of collaborations (above 30\%) with specialist I4.0 technology firms. We used a direct method of calibration (Ragin 2008), with the following thresholds: 0 for full set exclusion, 2.5 for set crossover, and 4 for full set inclusion. Finally, we considered whether MNEs sourced nationally from knowledge-intensive business services (KIBS), for example in the areas of R\&D, IT services and logistics. We defined the condition NATKIBS as the number of KIBS functions (R\&D, IT service and logistics) and amount of production MNEs subcontracted nationally. In particular, companies were asked to declare the percentage of activities subcontracted nationally, and we considered an activity which was performed nationally to be equal to 1 if a company carried out $50 \%$ or more of this activity by subcontracting in the home country, and 0 otherwise. To build NATKIBS, we computed the sum of the KIBS activities subcontracted nationally. We attached the value 1 to NATKIBS if operations and 1 KIBS activity were subcontracted nationally. We attached the value 2 to NATKIBS if operations and 2 KIBS activities were subcontracted nationally. We attached the value 3 to NATKIBS if operations and 3 KIBS activities were subcontracted nationally, and 0 otherwise. We used a four-value fuzzy-set scheme: fully out (0) if the condition was equal to 0 , more out than in (0.33) if the condition was equal to 1 , more in than out (0.67) if the condition was equal to 2 , fully in (1) if the condition was equal to 3 . The rationale behind that was based on the understanding that KIBS activities critically affect the competitiveness of manufacturing companies, especially in relation to I4.0. It can be argued that co-location with high-valued functions, such as KIBS, are crucial for firms as an alternative to having such competences in-house.

Set 3: Global drivers were captured by the condition "reliance on foreign suppliers" (GVC). Companies were asked to indicate the extent to which their key supplier firms were located outside the home country. We recorded the respondents' replies in the following way: 0 for low presence and 100 for high presence. We used a direct method of calibration (Ragin 2008), with the following thresholds: 25 for full set exclusion, 50 for set crossover, and 75 for full set inclusion.

\subsection{Models}

We ran three models with the same outcome conditions (PR), but with different sets of conditions. Figure 1 and Table 3 provide an overview of the configurational models under investigation. In particular, each model was designed in an attempt to shed light on the balance between the above three sets of determinants in terms of MNEs performance.

Footnote 9 (continued)

mented reality); and (4) digital-to-physical conversion (additive manufacturing/3D printing, advanced robotics). 


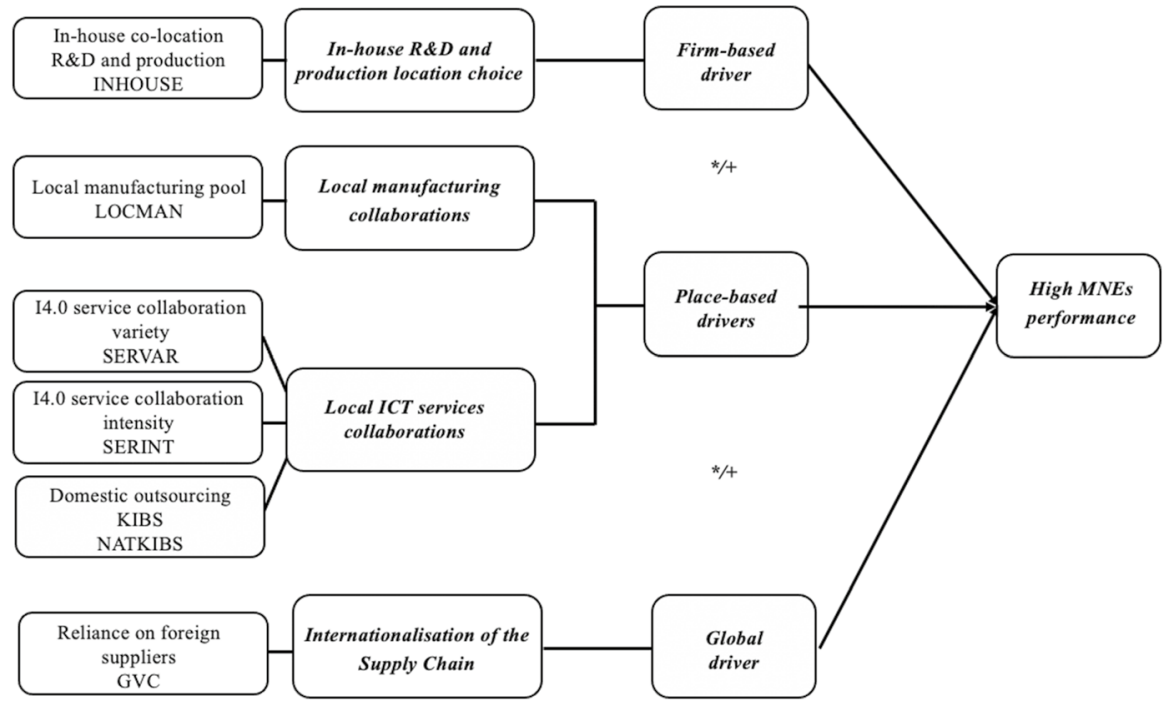

Fig. 1 Configurational model of high-level company performance. Note: $*=$ conjunction of conditions; $+=$ substitutable/equifinal paths

\section{Results and discussion}

We ran the necessity analysis for the presence as well as the absence of highlevel company performance for each of the three models described in Table $4 .{ }^{10}$ None of the conditions is necessary for the high-level company performance or its absence since none of them exceeds the threshold of 0.9.

Table 4 contains the 'conservative solutions', ${ }^{11}$ made up of only the empirically observed combinations of causal conditions incorporated into the minimization process. Each solution describes a sufficient combination of conditions leading to the outcome. In each of the three models, all the configurations consist of combinations of conditions, and no condition alone would be sufficient to account for high-level company performance. We followed Ragin and Fiss (2008) in representing findings graphically: the presence of a condition in a configuration is marked by a black circle, while its absence is marked by a crossed white circle. It is standard in discussing QCA findings to write conditions in uppercase letters (e.g., INHOUSE) when present, and in lowercase letters (e.g., inhouse) when absent.

In fs/QCA, consistency and coverage are two parameters which define the extent to which the results 'fit' the data (Ragin 2008). Consistency assesses the degree to

\footnotetext{
${ }^{10}$ Necessity analyses are available from the author(s) on request.

11 Since we compared different models, we considered only conservative solutions, without making any assumptions about the remainders. The results of intermediate and parsimonious solutions are available from the author(s) on request.
} 


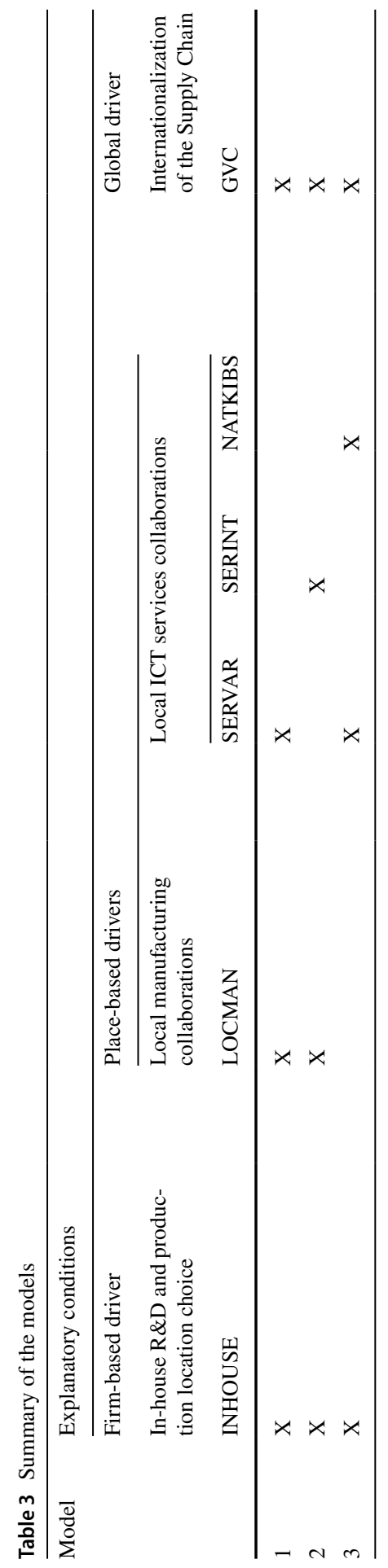




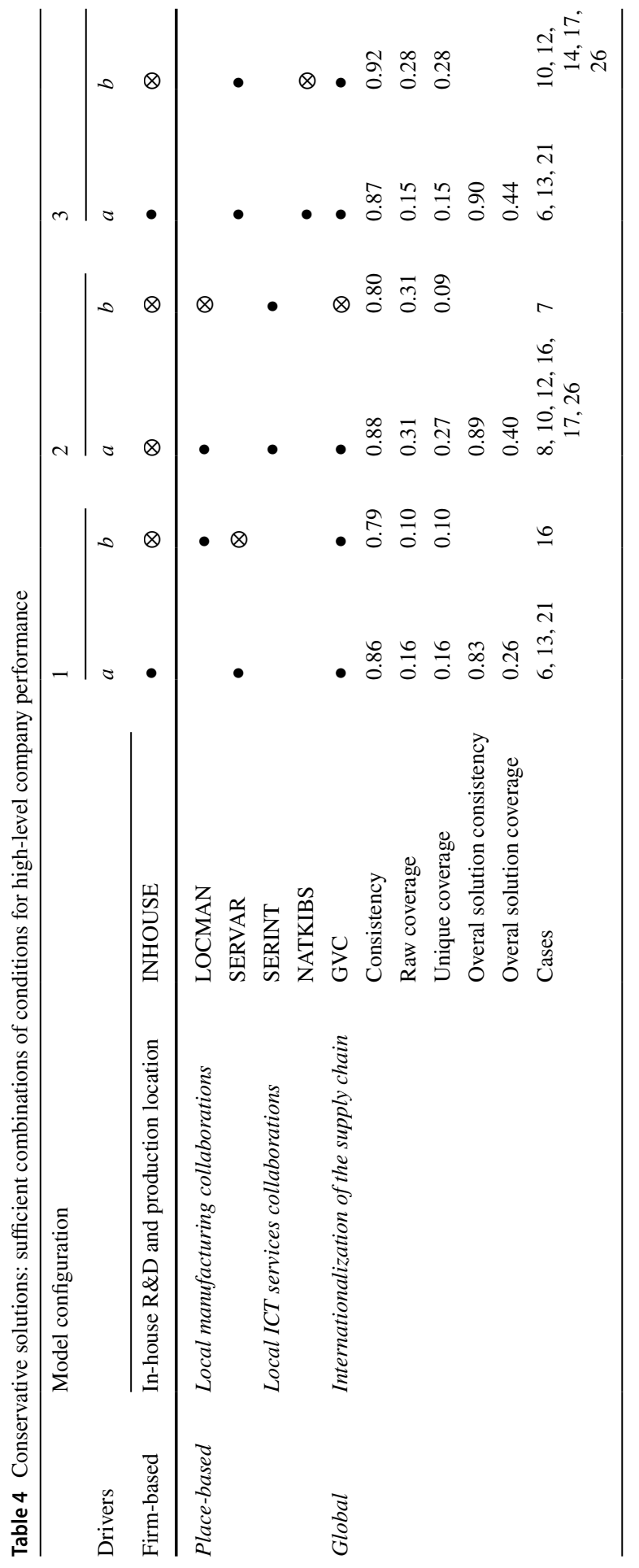


which cases sharing a given combination of conditions agree in displaying the outcome of interest. Consistency is measured as the number of cases featuring both a given configuration and the outcome divided by the number of cases featuring the same configuration, but not featuring the outcome (Ragin 2008). Overall solution consistency refers to the same measure but aggregated across all the identified configurations. We set the consistency threshold to at least 0.75 (Schneider and Wagemann 2012). The coverage of a solution term indicates the degree to which a cause or causal combination explains the outcome. Raw coverage is computed as the number of cases which present both the outcome and a given configuration divided by the number of cases featuring the outcome. Unique coverage is the number of cases featuring the outcome that are covered uniquely by a given configuration; that is, there are no other configurations covering those cases. It controls for overlapping explanations by partitioning raw coverage. Finally, overall solution coverage identifies the coverage measure aggregated across all the identified configurations. The overall solution coverage scores in Table 4 vary from 0.26 to 0.44 . This means that, at a minimum, the configurations analyzed account for about $26 \%$ of the instances of the outcome.

In Model 1, two configurations emerge as being empirically relevant. The first causal path (Configuration a) is INHOUSE*SERVAR*GVC. This means that a company can reach a high level of performance when the following three conditions are simultaneously present: (i) it carries out the majority of operations and R\&D inhouse in the home country (INHOUSE); (ii) it undertakes activities involving joint commitment of resources with specialist I4.0 technology firms (SERVAR); and, (iii) it builds an international network of suppliers (GVC). However, when companies carry out neither the majority of operations and R\&D domestically in-house (inhouse) nor have a variety of collaborations with specialist I4.0 technology firms (servar), then Configuration (b) (inhouse*LOCMAN*servar*GVC) suggests that they compensate with intense collaborations with a wide range of cross-sector local manufacturing companies (LOCMAN) while relying on links with international suppliers (GVC).

The key role played by collaborations with specialist I4.0 technology firms also emerges in Model 2. Indeed, Configuration (a) (inhouse*LOCMAN*SERINT* GVC) demostrates that in the absence of domestic in-house R\&D (in-house), a sufficient condition for high-level MNEs performance is to build intense collaborations with specialist I4.0 technology firms (SERINT) and collaborations with firms operating across manufacturing sectors (LOCMAN) located in the same region, whilst developing an international suppliers' network (GVC). Configuration (b) (inhouse*locman*SERINT*gve) also highlights the importance of the local dimensions and intense collaborations with specialist I4.0 technology firms (SERINT), as this alone delivers non-inferior performance.

In Configuration (a) of Model 3 (INHOUSE*SERVAR*NATKIBS*GVC), MNEs that produce as well as develop R\&D intra-muros (INHOUSE) can increase their performance if they: (i) invest in building an international supply network (GVC); (ii) seek to create a variety of collaborations with specialist I4.0 technology firms (SERVAR); and, (iii) outsource KIBS functions nationally (NATKIBS). Conversely, in Configuration (b) (inhouse*SERVAR*natkibs*GVC), the presence 
of activities involving joint commitments of resources with specialist I4.0 technology firms (SERVAR) becomes crucial for achiving high performance in conjunction with an international supply network (GVC), in the absence of national level KIBS (natkibs) and in-house operation and R\&D (inhouse).

The fc/QCA allows us to identify different, but equally successful, paths that can result in MNEs being highly performant. The findings suggest that high performance is mainly driven by simultaneous engagement in local and global linkages, with a robust access to the new I4.0 technologies (see Table 5).

With the exception of Configuration (b) in Model $2,{ }^{12}$ relying on a network of international suppliers is a condition that is present in all the highly performant companies. This finding is in line with GVC literature highlighting that participation in a GVC enables a company to be exposed to new complementary external knowledge which, in turn, should lead enhanced performance (De Marchi et al. 2017). Simultaneously, the presence of local links through active engagement in collaborations with firms located in the same region plays a pivotal role in achieving highlevel performance. This result is consistent with the literature on economic geography and regional studies which establishes the importance of the regional stock of competences and know-how for the long-term competitiveness of companies and the regional industrial common (Pisano and Shih 2009, 2012; Berger 2013) with an increasing trend toward closer value chains for knowledge-intensive production (Bailey et al. 2018). Finally, in the light of emerging industrial dynamics associated with a new manufacturing model and an increasing body of literature on 'smart' technologies (Wiegmann et al. 2017) and 'smart' products embodying such technologies (Porter and Heppelmann 2014), our results show that actively engaging with specialist local I4.0 firms, either in terms of variety of collaborations (SERVAR) or the intensity of collaborations (SERINT), is associated with high-level performance. This finding complements the case study in Bremen, Germany by Liu et al. (2019) on the emergence of collaborative partnerships between KIBS and product companies.

\section{Conclusions}

In this article, we focus on MNEs and considers performance drivers by focusing on the interplay between firm-based, place-based and global drivers in terms of firms performance, with a particular focus on new enabling technologies linked to I4.0. Previous studies on international business, economic geography and GVCs have shown the impact of these firm, place and global determinants on the performance of MNEs by focusing mainly on the net effects of each factor separately. The novelty

\footnotetext{
12 This configuration, however, seems to confirm the need for the co-presence of local and extra-local dimensions. Indeed, the highly performant company (namely, Case 7) balances a local network of suppliers (gvc) with a marginal involvement in carrying out activities with local manufacturers (locman) and the absence of in-house co-location of operations and KIBS (inhouse).
} 


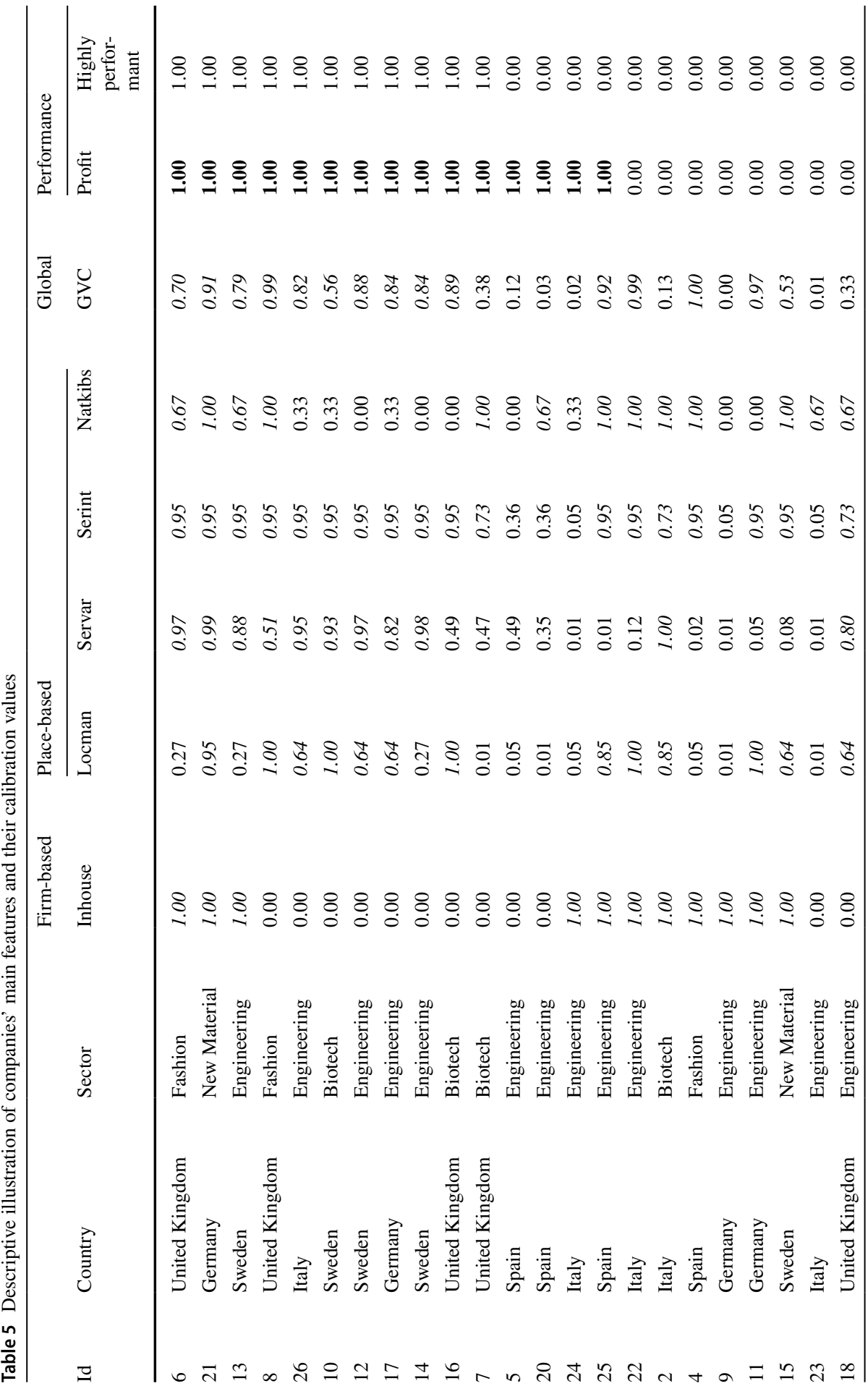




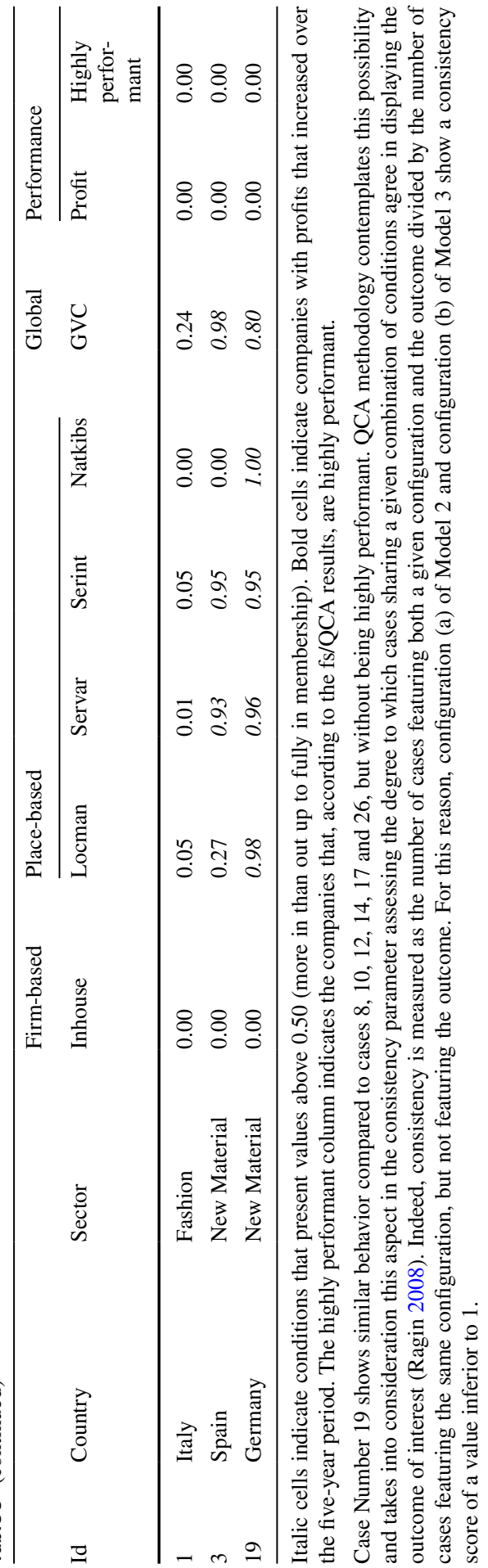


of our contribution is to shed light on their relative importance and their interplay with one another thanks to the fc/QCA methodology.

Our findings indicate that MNEs can be highly profitable by following different, but equally successful, paths. In particular, the set of configurations used in our fs/ QCA analysis highlights that MNEs can reach a high level of performance by balancing global linkages and place-based drivers, especially local access to I4.0 technologies. This result contributes to regional studies literature as well as the current debate on technological change, which points to the pervasive impact of digital technologies on manufacturing companies, and, ultimately, regional sustainability. By evidencing the need for a balance between global dimensions and local dimensions linked to new 'smart' technologies (Wiegmann et al. 2017), this research finds that MNEs achieve greater profit growth if they are part of a GVC and simultaneously involved in local collaborations with specialist I4.0 companies. Given the rise of disruptive new technologies and of the related new manufacturing model, I4.0, our findings seem to suggest that- in order to be highly performant -companies should be able to access and actively engage with these technologies locally.

The use of fs/QCA in this study also represents an important methodological contribution to regional science research. The use of set-theoretic methods has increased considerably in the last ten years in other disciplines (e.g., Grandori and Furnari 2008, Fiss 2011, Bell et al. 2014); however, despite an increasing number of applications (Ragin 2008: 177; Whittington and Bell 2016; Mas-Verdu et al. 2016), the usefulness of fs/QCA in testing hypotheses is "still underexploited" in regional studies. fs/QCA is a valuable tool for assessing the contribution of equally relevant factors to one certain outcome (Whittington and Bell 2016). This research is among the first to employ fs/QCA and provides original empirical contributions to describe the complementarity and balance between three sets of determinants affecting companies' performance. As such, this study is methodologically novel as well as contributing to our understanding of how companies balance local, regional and national linkages in an age of technological disruptions.

Policy implications emerge from this work. While MNEs rely on a network of international suppliers, we find that they still maintain strong home links. Their embeddedness is related to the use of the stock of industrial commons in the regional economy of their home country and its ability to surf the recent disruptive wave of new technologies. From a policy point of view, this means that to avoid footloose behaviors, interventions need to sustain the presence of the variety of competences in the regional economy by enhancing local collaborations, both within and among manufacturing and service sectors. In particular, local authorities should encourage the formation of new firms in the area of new enabling technologies (such as cyberphysical systems, automation, cognitive computing, and data exchange). Industrial policymakers should recognize the importance of maintaining and attracting advanced manufacturing to a location and enabling technologies linked to it, as well as of fostering local linkages to develop both company and regional competitiveness. In turn, through knowledge spillovers and a multiplier effect, this could create highly skilled jobs in manufacturing and lead to their retention, anchoring highvalue services in the regional economy (Bailey et al. 2018). 
This study is not without limitations. We believe that the quality of workers' skills and the geography of skill are critical transversal factors in the evaluation of drivers which lead to high-level firm performance in the context of the current digital transformations in advanced economies. Future research is required to reflect upon the impact of the educational attainment of different categories of workers as well as the impact of the geographical dimension in talent sourcing (be it local and/or global) on high-level firm performance. Future study is needed to evaluate the interplay of talent drivers with firm, local and global drivers leading to high-level firm performance in the light of recent digital transformations and deglobalization trends (De Propris and Pegoraro 2019).

Acknowledgements This work was supported by the European Commission's Marie-Curie Actions (Project Nr. H2020-MSCA-IF-2014 Proposal No. 660022, Project Acronym: SkillUP).

Open Access This article is licensed under a Creative Commons Attribution 4.0 International License, which permits use, sharing, adaptation, distribution and reproduction in any medium or format, as long as you give appropriate credit to the original author(s) and the source, provide a link to the Creative Commons licence, and indicate if changes were made. The images or other third party material in this article are included in the article's Creative Commons licence, unless indicated otherwise in a credit line to the material. If material is not included in the article's Creative Commons licence and your intended use is not permitted by statutory regulation or exceeds the permitted use, you will need to obtain permission directly from the copyright holder. To view a copy of this licence, visit http://creativecommons.org/licen ses/by/4.0/.

\section{References}

Andersson M, Stone T-A (2017) Global sourcing and technical efficiency—a firm-level study on the ICT industry in Sweden. J Bus Econ Manag 18:877-896

Asheim BT, Isaksen A (2002) Regional innovation systems: the integration of local 'sticky'and global 'ubiquitous' knowledge. J Technol Transf 27:77-86

Aversa P, Furnari S, Haefliger S (2015) Business model configurations and performance: a qualitative comparative analysis in Formula One racing, 2005-2013. Ind Corp Change 24:655-676

Bailey D, Corradini C, de Propris L (2018) 'Home-sourcing' and closer value chains in mature economies: the case of Spanish manufacturing. Camb J Econ 42:1567-1584

Bailey D, De Propris L (2014) Manufacturing reshoring and its limits: the UK automotive case. Camb J Regions Econ Soc rsu019

Baldwin R (2011) Trade and industrialisation after globalisation's 2nd unbundling: how building and joining a supply chain are different and why it matters. National Bureau of Economic Research

Barzotto M, Corò G, Volpe M (2017) Global value chains and the role of MNEs in local production systems. In: De Marchi V, Di Maria E, Gereffi G (eds) Local clusters in global value chains. Linking actors and territories. Routledge, London

Basile R, Pittiglio R, Reganati F (2017) Do agglomeration externalities affect firm survival? Reg Stud 51:548-562

Bathelt H, Malmberg A, Maskell P (2004) Clusters and knowledge: local buzz, global pipelines and the process of knowledge creation. Prog Hum Geogr 28:31-56

Becattini G, Rullani E (1996) Local systems and global connections: the role of knowledge. In: Cossentino F, Pyke F, Sengenberger W (eds) Local and regional response to global pressure: the case of Italy and its industrial districts. International Institute for Labour Studies, Geneva

Beckman S, Sinha KK (2005) Conducting academic research with an industry focus: production and operations management in the high tech industry. Prod Oper Manag 14:115-124 
Bell RG, Filatotchev I, Aguilera RV (2014) Corporate governance and investors' perceptions of foreign IPO value: an institutional perspective. Acad Manag J 57:301-320

Bellandi M, Chaminade C, Plechero M (2020) Transformative paths, multi-scalarity of knowledge bases and Industry 4.0. In: De Propris L, Bailey D (eds) Industry 4.0 and Regional Transformations. Taylor \& Francis, New York, pp 62-83. https://doi.org/10.4324/9780429057984-4

Bellandi M, Santini E (2019) Territorial servitization and new local productive configurations: the case of the textile industrial district of Prato. Reg Stud 53:356-365

Berger S (2013) Making in America: from innovation to market. Mit Press, Cambridge

Billing CA, Bryson JR (2019) Heritage and satellite manufacturing: firm-level competitiveness and the management of risk in global production networks. Econ Geogr 1-19

Bontoux L, Boucher P, Scapolo F (2017) Textiles and clothing manufacturing: vision for 2025 and actions. Office of the European Union, Luxembourg

Boschma R, Iammarino S (2009) Related variety, trade linkages, and regional growth in Italy. Econ Geogr 85:289-311

Brakman S, Marrewijk C, Partridge M (2015) Local consequences of global production processes. J Region Sci 55:1-9

Breznitz D, Murphree M (2011) Run of the Red Queen. Government, innovation, globalization and economic growth in China. Yale University Press, New Haven, CT

Buciuni G, Corò G, Micelli S (2014) Rethinking the role of manufacturing in global value chains: an international comparative study in the furniture industry. Ind Corp Change 23:967-996

Buckley PJ, Casson M (1976) The future of the multinational enterprise. Macmillan, Basingstoke

Buckley PJ, Strange R (2011) The governance of the multinational enterprise: insights from internalization theory. J Manag Stud 48:460-470

Castellacci F (2008) Technological paradigms, regimes and trajectories: manufacturing and service industries in a new taxonomy of sectoral patterns of innovation. Res Policy 37:978-994

Coe NM, Hess M, Yeung HWC, Dicken P, Henderson J (2004) 'Globalizing'regional development: a global production networks perspective. Trans Inst Br Geogr 29:468-484

Collier D (1993) Comparative method. In: Finifter AW (ed) Political science: the state of discipline II. American Political Science Association, Washington, DC

Corradini C, de Propris L (2017) Beyond local search: bridging platforms and inter-sectoral technological integration. Res Policy 46:196-206

Courtright SH, Gardner RG, Smith TA, McCormick BW, Colbert AE (2016) My family made me do it: a cross-domain, self-regulatory perspective on antecedents to abusive supervision. Acad Manag J 59:1630-1652

Crescenzi R, Iammarino S (2017) Global investments and regional development trajectories: the missing links. Reg Stud 51:97-115

de Marchi V, di Maria E, Gereffi G (2017) Local clusters in global value chains. Linking Actors and Territories, London, UK, Routledge

De Propris L, Bailey D (2020) Industry 4.0 and Regional Transformations. Taylor \& Francis, New York, Routledge

De Propris L, Crevoisier O (2011) From regional anchors to anchoring. In: Cooke P, Asheim B, Boschma R, Martin R, Schwartz D, Tödling F (eds) Handbook of regional innovation and growth. Edward Elgar Publishing, Cheltenham, UK

de Propris L, Driffield N (2005) The importance of clusters for spillovers from foreign direct investment and technology sourcing. Camb J Econ 30:277-291

De Propris L, Pegoraro D (2019) Technological disruptions and production location choices. In: Chidlow A, Ghauri PN, Buckley T, Gardner EC, Qamar A, Pickering E (eds) The changing strategies of international business how MNEs manage in a changing commercial and political landscape. Palgrave, London

Decelles KA, Derue DS, Margolis JD, Ceranic TL (2012) Does power corrupt or enable? When and why power facilitates self-interested behavior. J Appl Psychol 97:681

Degennaro R (2005) Market imperfections, Federal Reserve Bank of Atlanta,". Working Paper" 2005-12, 07.2005

Demirel P, Parris S (2015) Access to finance for innovators in the UK's environmental sector. Technol Anal Strat Manag 27:782-808

Deutskens E, de Ruyter K, Wetzels M, Oosterveld P (2004) Response rate and response quality of internet-based surveys: an experimental study. Market Lett 15:21-36 
Divella M (2017) Cooperation linkages and technological capabilities development across firms. Reg Stud 51:1494-1506

Doyle P, Hooley GJ (1992) Strategic orientation and corporate performance. Int J Res Mark 9:59-73

Dunning JH (1981) International production and the multinational enterprises. Allen \& Unwin, London

Dunning JH (2000) The eclectic paradigm as an envelope for economic and business theories of MNE activity. Int Bus Rev 9:163-190

Duranton G, Puga D (2001) Nursery cities: urban diversity, process innovation, and the life cycle of products. Am Econ Rev 1454-1477

European Commission (2013) Competitiveness report 2013: no growth and jobs without industry. MEMO/13/815 25/09/2013

European Commission (2019) Innovation policies and advanced manufacturing support measures in Northern Central Sweden [Online]. Commission's Directorate-General for Internal Market, Industry, Entrepreneurship and SMEs. https://ec.europa.eu/growth/tools-databases/regional-innovation -monitor/news/innovation-policies-and-advanced-manufacturing-support-measures-northern-centr al-sweden [Accessed 05/06/2019]

Fiss PC (2007) A set-theoretic approach to organizational configurations. Acad Manag Rev 32:1180-1198

Fiss PC (2011) Building better causal theories: a fuzzy set approach to typologies in organization research. Acad Manag J 54:393-420

Fiss PC, Sharapov D, Cronqvist L (2013) Opposites attract? Opportunities and challenges for integrating large-N QCA and econometric analysis. Political Res Q 191-198

Fragale AR, Sumanth JJ, Tiedens LZ, Northcraft GB (2012) Appeasing equals: lateral deference in organizational communication. Adm Sci Q 57:373-406

Frank AG, Dalenogare LS, Ayala NF (2019) Industry 4.0 technologies: implementation patterns in manufacturing companies. Int J Prod Econ 210:15-26

Frenken K, van Oort F, Verburg T (2007) Related variety, unrelated variety and regional economic growth. Reg Stud 41:685-697

Galperin, R. V., Hahl, O., Sterling, A. D. \& Guo, J (2019) Too good to hire? Capability and inferences about commitment in labor markets. Admin Sci Q 0001839219840022

Gereffi G, Humphrey J, Kaplinsky R (2001) Introduction: globalisation, value chains and development. IDS bulletin 32:1-8

Glaeser EL, Kallal HD, Scheinkman JA, Shleifer A (1992) Growth in cities. J Political Econ 100:1126-1152

Gorard S (2013) Research design: creating robust approaches for the social sciences. Sage, London

Grandori A, Furnari S (2008) A chemistry of organization: combinatory analysis and design. Org Stud 29:459-485

Grauvogel J, von Soest C (2014) Claims to legitimacy count: why sanctions fail to instigate democratisation in authoritarian regimes. Eur J Political Res 53:635-653

Greckhamer T, Misangyi VF, Fiss PC (2013) Chapter 3 the two QCAs: from a small-N to a large-N set theoretic approach. Configurational theory and methods in organizational research. Emerald Group Publishing Limited

Gugler P, Keller M, Tinguely X (2015) The role of clusters in the global innovation strategy of MNEs: theoretical foundations and evidence from the Basel pharmaceutical cluster. Compet Rev 25:324-340

Hausmann R, Hidalgo CA, Bustos S, Coscia M, Simoes A, Yildirim MA (2014) The atlas of economic complexity: mapping paths to prosperity. Mit Press, Cambridge

Hennart J-F (1982) A theory of multinational enterprise, Univ of Michigan Pr

Hewings GJ (2008) On some conundra in regional science. Ann Reg Sci 42:251-265

Jacobs J (1969) The economy of cities. Random House, New York

Ketokivi M, Ali-Yrkkö J (2009) Unbundling R\&D and manufacturing: postindustrial myth or economic reality? Rev Policy Res 26:35-54

Lafuente E, Vaillant Y, Vendrell-Herrero F (2017) Territorial servitization: exploring the virtuous circle connecting knowledge-intensive services and new manufacturing businesses. Int J Prod Econ 192:19-28

Lee J, Bagheri B, Kao H-A (2015) A cyber-physical systems architecture for industry 4.0-based manufacturing systems. Manuf Lett 3:18-23

Liu Y, Lattemann C, Xing Y, Dorawa D (2019) The emergence of collaborative partnerships between knowledge-intensive business service (KIBS) and product companies: the case of Bremen, Germany. Reg Stud 53:376-387 
Long CP, Bendersky C, Morrill C (2011) Fairness monitoring: linking managerial controls and fairness judgments in organizations. Acad Manag J 54:1045-1068

Malecki EJ (2010) Global knowledge and creativity: new challenges for firms and regions. Reg Stud 44:1033-1052

Marcus B, Bosnjak M, Lindner S, Pilischenko S, Schütz A (2007) Compensating for low topic interest and long surveys: a field experiment on nonresponse in web surveys. Soc Sci Comput Rev 25:372-383

Marr MD (2012) Pathways out of homelessness in Los Angeles and Tokyo: multilevel contexts of limited mobility amid advanced urban marginality. Int J Urban Reg Res 36:980-1006

Marra M (2014) What coordination mechanisms work to manage regional development programmes? Insights from Southern Italian regions. Eur Urban Reg Stud 21:254-271

Marsh P (2013) The new industrial revolution. Yale University Press, London

Marshall A (1980) Principles of economics. Macmillan, London

Martin R, Aslesen HW, Grillitsch M, Herstad SJ (2018) Regional innovation systems and global flows of knowledge. In: Isaksen A, Martin R, Trippl M (eds) New Avenues for Regional Innovation Systems: Theoretical Advances, Empirical Cases and Policy Lessons. Springer, Cham

Martynovich M, Lundquist K-J (2015) Technological change and geographical reallocation of labour: on the role of leading industries. Reg Stud 1-15

Mas-Verdu F, Ortiz-Miranda D, García-Álvarez-coque JM (2016) Examining organizational innovations in different regional settings. J Bus Res 69:5324-5329

Medina I (2016) Are business associations involved in regional politics? Evidence from Spain and the United Kingdom. Eur Urban Region Stud 23:389-405

Merlin-Jones D (2012) The boomerang economy: why british offshored manufacturers are returning home and how to maximise this trend. Institute for the Study of Civil Society, Civitas

Morgan NA, Slotegraaf RJ, Vorhies DW (2009) Linking marketing capabilities with profit growth. Int J Res Mark 26:284-293

Myers MB, Cheung M-S (2008) Sharing global supply chain knowledge. MIT Sloan Manag Rev 49:67

Nakamura D (2010) An integrated production-stage analysis on market areas and supply areas. Ann Reg Sci 45:453-471

Neely A (2008) Exploring the financial consequences of the servitization of manufacturing. Oper Manag Res 1:103-118

OECD (2017) The next production revolution: implications for governments and business. OECD Publishing, Paris

OECD O. F. E. C.-O. A. D (2016) Enabling the next production revolution: the future of manufacturing and services-Interim report

Parry G, Bustinza OF, Vendrell-Herrero F (2012) Servitisation and value co-production in the UK music industry: an empirical study of consumer attitudes. Int J Prod Econ 135:320-332

Phelps NA (2008) Cluster or capture? Manufacturing foreign direct investment, external economies and agglomeration. Reg Stud 42:457-473

Pisano GP, Shih WC (2009) Restoring American competitiveness. Harvard Bus Rev 87:114-125

Pisano GP, Shih WC (2012) Does America really need manufacturing? Harvard Bus Rev 90:94-102

Porter ME, Heppelmann JE (2014) How smart, connected products are transforming competition. Harvard Bus Rev 92:64-88

Potter A, Watts HD (2011) Evolutionary agglomeration theory: increasing returns, diminishing returns, and the industry life cycle. J Econ Geogr 11:417-455

Powell WW (1998) Learning from collaboration: knowledge and networks in the biotechnology and pharmaceutical industries. California Manag Rev 40:228-240

Probst L, Monfardini E, Frideres L, Demetri D, Kauffmann A, Clarke S (2013) Advanced manufacturing. Mass customisation, Business Innovation Observatory, European Commission

Ragin CC (1987) The comparative method: moving beyond qualitative and quantitative strategies. University of California Press, California

Ragin CC (2008) Redesigning social inquiry: fuzzy sets and beyond. Wiley, Amsterdam

Ragin CC, Fiss PC (2008) Net effects analysis versus configurational analysis: an empirical demonstration. Redesigning social inquiry: fuzzy sets and beyond. University of Chicago Press, Chicago, MA

Ramirez P (2016) To what extent and in what manner do chinese and indian contract research organisation learn and upgrade with the unbundling the global pharmaceutical R\&D value chain? 28th annual conference of the society for the advancement of socio-economics. California (USA), Berkeley 
Rebolledo C, Nollet J (2011) Learning from suppliers in the aerospace industry. Int J Prod Econ 129:328-337

Ross A (2016) The industries of the future. Simon and Schuster, New York

Schneider CQ, Wagemann C (2012) Set-theoretic methods for the social sciences: a guide to qualitative comparative analysis. Cambridge University Press, Cambridge

Schneider MR, Schulze-Bentrop C, Paunescu M (2010) Mapping the institutional capital of high-tech firms: a fuzzy-set analysis of capitalist variety and export performance. J Int Bus Stud 41:246-266

SEMTA (2009) Skills and the future of advanced manufacturing. A summary skills assessment for the SSC advanced manufacturing cluster. Semta-Sector skills council for science, engineering and manufacturing technologies

Singh M, Ohji T, Asthana R (2015) Green and sustainable manufacturing of advanced material. Elsevier, Amsterdam

Smit J, Kreutzer S, Moeller C, Carlberg M (2016) Industry 4.0. In: POLICY., D. G. F. I. P. P. D. A. E. A. S. (ed)

Storper M, Venables AJ (2004) Buzz: face-to-face contact and the urban economy. J Econ Geogr 4:351-370

Tao F, Cheng Y, Zhang L, Nee AY (2017) Advanced manufacturing systems: socialization characteristics and trends. J Intell Manuf 28:1079-1094

Trippl M, Tödtling F, Lengauer L (2009) Knowledge sourcing beyond buzz and pipelines: evidence from the Vienna software sector. Econ Geogr 85(4):443-462

UK GOVERNMENT (2017) Industrial strategy challenge fund: for research and innovation [Online]. https://www.gov.uk/government/collections/industrial-strategy-challenge-fund-joint-research-andinnovation\#manufacturing-and-future-materials [Accessed]

UNCTAD (2015) Trade aned development report. United Nations, New York

Vandermerwe S, Rada J (1988) Servitization of business: adding value by adding services. Eur Manag J 6:314-324

Verspagen B (2004) Structural change and technology. Revue Écon 55:1099-1125

Weinzimmer LG, Robin J, Michel EJ (2012) The measurement of strategic orientation and its efficacy in predicting financial performance. J Bus Strat 29:81

Whittington JL, Bell RG (2016) Leader-member exchange, enriched jobs, and goal-setting: applying fuzzy set methodology. J Bus Res 69:1401-1406

Wiegmann PM, de Vries HJ, Blind K (2017) Multi-mode standardisation: a critical review and a research agenda. Res Policy 46:1370-1386

Yew A, Ong S, Nee A (2016) Towards a griddable distributed manufacturing system with augmented reality interfaces. Robot Comput-Integr Manuf 39:43-55

Zirpoli F, Becker M (2011) What happens when you outsource too much? MIT Sloan Manag Rev 52:59

Publisher's Note Springer Nature remains neutral with regard to jurisdictional claims in published maps and institutional affiliations. 